\title{
MENINGKATKAN KECERDASAN EKOLOGIS MELALUI MODEL MULTILITERASI BERBASIS ECOPEDAGOGY APPROACH
}

\author{
Dede Margo Irianto ${ }^{1}$, Hana Yunansah ${ }^{2}$, Yusuf Tri Herlambang ${ }^{3}$, Tita Mulyati ${ }^{4}$ \\ Universitas Pendidikan Indonesia Kampus Cibiru
}

\begin{abstract}
The problem in this research is based on the finding of the reality of the conditions of human life that have been trapped in the wrong development paradigm (maldevelopment), so as to see nature as an object, mechanistic, fragmented, and separated from humans so that it is easily dominated and exploited. Based on these thoughts, real solutions are needed as an effort to build a critical attitude and care in understanding various life phenomena that are detrimental to the environment. Therefore, ecological education is needed to hone ecological sensibility and foster awareness of the existence of the environment as part of an ecosystem that affects human life. Efforts to realize these conditions are initiated by manipulating appropriate educational models, one of which is a multiliteration model based on an ecopedagogy approach.
\end{abstract}

Keyword: Multiliteration, Ecopedagogic, Ecological, Elementary School

\begin{abstract}
Abstrak: Masalah dalam penelitian ini didasarkan pada temuan adanya realitas kondisi kehidupan manusia yang telah terjebak dalam paradigma pembangunan yang keliru (maldevelopment), sehingga memandang alam sebagai objek, mekanistis, terpecah-pecah, dan terpisah dari manusia sehingga mudah didominasi dan dieksploitasi. Atas dasar pemikiran tersebut, diperlukan solusi nyata sebagai upaya membangun sikap kritis dan kepedulian dalam memahami berbagai fenomena kehidupan yang merugikan lingkungan hidup. Oleh sebab itu, pendidikan ekologis sangat dibutuhkan demi mengasah sensibilitas ekologis serta menumbuhkan kesadaran akan keberadaan lingkungan hidup sebagai bagian dari ekosistem yang berpengaruh terhadap kehidupan manusia. Upaya untuk mewujudkan kondisi tersebut diawali dari merekayasa model pendidikan yang tepat, salah satunya adalah model multiliterasi berbasis ecopedagogy approach.
\end{abstract}

Kata Kunci: Multiliterasi, Ekopedagogik, Ekologis, Sekolah Dasar.

'Universitas Pendidikan Indanesia Kampus Cibiru, Email: dedemarga 国upi.edu

2Universitas Pendidikan Indonesia Kampus Cibiru, Email: hanayunansah国upi.edu

${ }^{3}$ Universitas Pendidikan Indonesia Kampus Cibiru, Email: yusufth国upi.edu

${ }^{4}$ Universitas Pendidikan Indanesia Kampus Cibiru, Email: mulyati国upi.edu 


\section{PENDAHULUAN}

Pendidikan merupakan upaya memanusiakan manusia sesuai dengan hakikat kemanusiaannya sebagai makhluk multidimensi yang salah satunya ialah memiliki hubungan dengan alam atau lingkungan (Herlambang, 2018). Oleh sebab itu pendidikan akan senantiasa terkait erat dengan ruang dan waktu dimana relasi antara manusia dengan lingkungan alam mendapat tempatnya secara nyata yang mengimplikasikan kewajiban manusia untuk selalu menjaga keselarasan, keharmonisan, dan kesinambungan dengan alam (Muhaimin, 2015). Hal ini dikarenakan manusia dianggap sebagai bagian dari planet bumi (Freire, 2010; Misiaszek, 2012).

Berkaitan hal diatas, kondisinya berbanding terbalik dengan realitas yang ada saat ini. Meskipun pada dasarnya alam sendiri sudah diakui memiliki nilai dan berharga, tetapi pada kenyataannya, alam dianggap sebagai objek kehidupan yang terus di eksploitasi oleh manusia melalui praktik pencemaran, perusakan dan berbagai tindakan buruk lainnya. Kondisi ini merupakan cerminan dari rendahnya kesadaran ekologis dan krisis moral masyarakat. Hal ini diungkapkan pula oleh Machan (1989) bahwa krisis lingkungan hidup seperti semua krisis yang ditandai dengan perbuatan sejumlah orang yang merugikan sejumlah orang lainnya, baik karena lalai maupun disengaja, pada dasarnya merupakan krisis moral hukum. Oleh sebab itu, perlu adanya upaya dalam membangun sikap kritis dan kepedulian dalam memahami berbagai fenomena kehidupan yang merugikan lingkungan hidup melalui reposisi relasi manusia dengan alam/lingkungan hidup, hingga terbangun kesadaran akan etika dan moral lingkungan hidup (Herlambang \& Yunansah, 2017).

Sejalan dengan hal tersebut, pendidikan ekologis sangat dibutuhkan demi mengasah sensibilitas ekologis serta menumbuhkan kesadaran akan keberadaan lingkungan hidup sebagai bagian dari ekosistem yang berpengaruh pada kehidupan manusia. Dalam dan melalui pendidikan ekologis, semua orang digiring kepada pembiasaan mentalitas hidup ekologis yang senantiasa sadar bahwa keberadaan dirinya hanya bisa berarti kalau ia ada bersama dengan ciptaan lain. Hal ini berimplikasi pada pemahaman tentang betapa bernilai dan berharganya alam bagi kehidupan manusia, bahwa pentingnya menjaga dan melestarikan kehidupan yang selaras dan seimbang.

Kesadaran ekologis harus menjadi bagian terpenting dari tujuan pendidikan. Pendidikan harus mampu membangun insan-insan pendidikan yang memiliki karakter dan kesadaran tentang alam/lingkungan dan bukan diorientasikan pada upaya untuk melahirkan insan-insan pendidikan yang berjiwa pragmatismaterialis, dan berdampak pada terbangunnya paradigma yang terjebak dalam rimba-raya pembangunan yang keliru (maldevelopment) yang hanya melihat alam sebagai obyek, mekanistis, terpecah-pecah, terpisah dari manusia sehingga mudah didominasi dan dieksploitasi.

Dengan demikian maka dapat dipahami bahwa kesadaran ekologis tidaklah dibangun melalui sebuah proses pendidikan yang hanya bersifat transfer of knowledge, melainkan sebuah proses pembelajaran yang menempatkan peserta didik sebagai subjek aktif dalam pembelajaran. Pendidikan yang membangun kesadaran dan kecerdasan ekologis dengan berorientasi pada transfer of knowledge hanya akan membuat peserta didik hanya sebatas memiliki pengetahuan tentang lingkungan, dan kurang memiliki kesadaran dan kepedulian terhadap lingkungan (Muhaimin, 2015). Hal ini pun berdampak buruk pada karakter peserta didik yang pada umumnya belum bersikap dan berkelakuan ramah terhadap lingkungan (Soemarwoto, 2001; Supriatna, 2002). Hal ini tampak dengan bertebarannya sampah dilingkungan sekolah, beralih fungsinya toilet menjadi 
tempat buang tisu, pembungkus dan lainlain seperti dapat disaksikan disebagian besar sekolah menunjukkan bahwa kalangan terdidik tidak memiliki kompetensi/ kecerdasan ekologis (Muhaimin, 2015).

Membangun pengetahuan secara mandiri secara bermakna dapat dilakukan melalui beberapa model pembelajaran, salah satunya ialah model Multiliterasi. Multiliterasi merupakan dasar penyelenggaraan pendidikan dan pembelajaran yang berorientasi pada upaya dalam membangun wawasan dan pemahaman peserta didik agar mereka mampu mengembangkan keterampilan berpikir (kritis, kreatif, problem solving, dan metakognisi) yang didasarkan dan dikembangkan melalui latar belakang sosial budaya (Cope and Kalantzis, 2005). Hal ini dipertegas dengan pendapat Ivanic (2009) yang menyatakan bahwa pendidikan multiliterasi merupakan proses memberikan tantangan kepada peserta didik untuk mengkaji dan menerapkan literasi praktis yang berfungsi sebagai alat mediasi untuk mempelajari berbagai konsep lintas kurikulum. Iyer \& Luke (2010) mengungkapkan bahwa melalui pendekatan Multiliterasi peserta didik akan memperoleh pemahaman yang tinggi. Sejalan dengan hal tersebut, Abidin (2015) berpendapat bahwa Multiliterasi juga diyakini mampu mengembangkan kreativitas tingkat tinggi sebagai keterampilan paling penting bagi peserta didik.

Bertemali dengan hal tersebut, multiliterasi merupakan sebuah model pembelajaran yang berorientasi pada pengembangkan kemampuan Multiliterasi yang didasarkan pada fenomena kehidupan yang ada dan bertujuan untuk membangun pengetahuan dan kesadaran secara kritis terhadap kondisi sosio-kultural. Multiliterasi diyakini dapat menjadi solusi dalam memecahkan berbagai problematika pembelajaran saat ini yang telah kehilangan makna karena masih bersifat tekstual-parsial, dan bukan konstekstual- integratif. Hal ini sesuai dengan pendapat Concannon-Gibney dan McCarthy (2012) berdasarkan penelitiannya, yang menyimpulkan bahwa "Multiliteracies education plays a key role in science achievement". Dengan kata lain bahwa pendidikan multiliterasi menjadi kunci utama dalam pencapaian ilmu pengetahuan

Berdasarkan pada hal di atas, telah dilakukan penelitian tentang model multiliterasi berbasis Ecopedagogy Approach pada jenjang sekolah dasar yang bertujuan untuk meningkatkan kompetensi ekologis dan pengembangan karakter. Hal ini tentu dianggap sebagai upaya yang bersifat urgen dan krusial dalam kondisi pembelajaran saat ini yang telah jauh melenceng dari hakikatnya, yaitu terpisahnya antara teks dan konteks yang akan berdampak signifikan pada lepasnya makna dan nilai pembelajaran yang tercerabut dari kehidupan serta berimbas pada rendahnya kompetensi ekologis dan rendahnya karakter. Selain itu, jenjang sekolah dasar merupakan jenjang pendidikan yang memiliki fungsi strategis untuk mengembangkan potensi dan membekali peserta didik dengan berbagai ilmu pengetahuan bermakna untuk membangun kesadaran dan karakter peserta didik.

\section{METODOLOGI PENELITIAN}

Metode penelitian yang digunakan dalam penelitian ini adalah penelitian mixed methods. Penelitian mixed methods sendiri dapat dibagi menjadi empat, yakni tipe embedded, explanatory, exploratory, dan triangulation (Cresswell, 2007). Dari keempat tipe desain penelitian di atas, tipe penelitian yang akan digunakan adalah tipe explanatory. Pemilihan tipe eksplanatori sejalan dengan tahapan penelitian yang dilaksanakan yakni data yang akan diambil penulis pertama kali merupakan data kuantitatif berupa proses dan hasil dan proses belajar peserta didik. Data kuantitatif tersebut akan diolah menggunakan statistik untuk membuktikan hipotesis dalam penelitian ini. Kemudian 
setelah hipotesis penelitian terbukti, selanjutnya analisis data kualitatif digunakan untuk menjelaskan temuantemuan penelitian yang mendukung pembuktian hipotesis kuantitatif.

Subjek penelitian ditentukan dengan cara purposif sampling. Penelitian ini akan dilaksanakan di sekolah dasar yang berada pada beberapa wilayah provinsi di Indonesia yang meliputi provinsi Jawa Barat, provinsi Jawa Tengah dan provinsi Bali sebagai objek dalam penerapan dan pengembangan konsep Model Multiliterasi berbasis Ecopedagogy Approach.

Instrumen yang digunakan untuk mengumpulkan data penelitian ini adalah (1) tes untuk mengukur kompetensi ekologis, baik pengetahuan, sikap, keterampilan dan partisipasi , (2) penilaian proses berbentuk skoring rubrik untuk

mengukur kompetensi ekologis, (4) catatan lapangan untuk mengumpulkan data hasil kegiatan observasi, dan (5) dokumentasi untuk mengumpulkan data proses pelaksanaan penelitian.

Berdasarkan jenis instrumen yang digunakan, penelitian ini akan menghasilkan dua jenis data yakni data kualitatif dan data kuantitatif. Data kualitatif tersebut akan dianalisis dengan menggunakan teknik induktif dengan tahapan (1) mengumpulkan, membaca, dan mempelajari data melalui penandaan katakata kunci dan gagasan yang ada dalam data; (2) klasifikasi data berdasarkan tematema data; (3) menuliskan 'pola-pola' yang ditemukan; dan (4) memaknai data yang dihasilkan.

Data kuantitatif yang dihasilkan dalam penelitian ini adalah data yang berhubungan dengan hipotesis yang diajukan yakni peningkatan kompetensi ekologis. Data ini akan dianalisis dengan menggunakan metode statistik yaitu uji beda ( $\mathrm{t}$ ) dengan bantuan SPSS versi 18, sementara untuk analisis adanya interaksi model digunakan metode statistik yaitu analisis Anova dengan bantuan SPSS versi 18.

\section{HASIL PENELITIAN \\ PEMBAHASAN}

\section{Uji Hipotesis Pertama}

Hipotesis pertama yang diuji dalam penelitian ini adalah model multiliterasi berbasis ecopedagogy approach berpengaruh secara signifikan terhadap kecerdasan ekologis pada siswa kelas eksperimen. Berdasarkan hasil uji $t$ terhadap perbandingan nilai kecerdasan ekologis di kelas eksperimen diperoleh data sebagai berikut.

Tabel 1 Hasil Uji Perbandingan Nilai Nilai Kecerdasan ekologis antara Pretes dan Postes Kelas Eksperimen

\begin{tabular}{|c|c|c|c|}
\hline & Pair 1 \\
\hline & & & $\begin{array}{l}\text { Postes Eksperimen } \\
\text { - Pretes } \\
\text { Eksperimen }\end{array}$ \\
\hline \multirow{5}{*}{$\begin{array}{l}\text { Paire } \\
\text { d } \\
\text { Diffe } \\
\text { renc } \\
\text { es }\end{array}$} & Mean & & 2.95385 \\
\hline & Std. Deviation & & 15.56987 \\
\hline & Std. Error Mean & & 1.36557 \\
\hline & $95 \%$ & Lower & 26.83665 \\
\hline & $\begin{array}{l}\text { Confidence } \\
\text { Interval of the } \\
\text { Difference }\end{array}$ & Upper & 32.24027 \\
\hline \multicolumn{3}{|l|}{$T$} & 21.631 \\
\hline \multicolumn{3}{|c|}{ Df } & 129 \\
\hline \multicolumn{3}{|c|}{ Sig. (2-tailed) } & ,000 \\
\hline
\end{tabular}

Berdasarkan tabel di atas dapat dikemukakan bahwa nilai t hitung sebesar 21,63. Besaran nilai Sig. (2-tailed) adalah 0,00. Ternyata nilai Sig. (2-tailed) lebih kecil dibanding taraf signifikasi (alfa) 0,05 . Hal ini berarti terdapat perbedaan antara nilai kecerdasan ekologis siswa pada saat pretes dan postes pada siswa kelas eksperimen. Dengan demikian hipotesis kerja penelitian ini diterima. Artinya implementasi model multiliterasi berbasis ecopedagogy approach berpengaruh secara signifikan terhadap kecerdasan ekologis siswa pada siswa kelas eksperimen.

\section{Uji Hipotesis Kedua}

Hipotesis kedua yang diuji dalam penelitian ini adalah model terlangsung berpengaruh secara signifikan terhadap 
kecerdasan ekologis pada siswa kelas kontrol. Berdasarkan hasil uji t terhadap perbandingan nilai kecerdasan ekologis siswa di kelas kontrol diperoleh data sebagai berikut.

Tabel 2 Hasil Uji Perbandingan Nilai Kecerdasan ekologis siswa antara Pretes dan Postes Kelas Kontrol

\begin{tabular}{|c|c|c|c|}
\hline & Pair 1 \\
\hline & & & $\begin{array}{l}\text { Postes } \\
\text { Kontrol - } \\
\text { Pretes } \\
\text { Kontrol }\end{array}$ \\
\hline \multirow{5}{*}{$\begin{array}{l}\text { Paired } \\
\text { Difference } \\
s\end{array}$} & Mean & & 2.38077 \\
\hline & Std. Deviation & & 16.28006 \\
\hline & Std. Error Mean & & 1.42786 \\
\hline & $95 \%$ Confidence & Lower & 20.98265 \\
\hline & $\begin{array}{l}\text { Interval of the } \\
\text { Difference }\end{array}$ & Upper & 26.63274 \\
\hline & 16.674 \\
\hline \multicolumn{3}{|c|}{ Df } & 129 \\
\hline \multicolumn{3}{|c|}{ Sig. (2-tailed) } &, 000 \\
\hline
\end{tabular}

Berdasarkan tabel di atas dapat dikemukakan bahwa nilai t hitung sebesar 11,33. Besaran nilai Sig. (2-tailed) adalah 0,00. Ternyata nilai Sig. (2-tailed) lebih kecil dibanding taraf signifikasi (alfa) 0,05. Hal ini berarti terdapat perbedaan antara nilai kecerdasan ekologis siswa pada saat pretes dan postes pada siswa kelas kontrol. Dengan demikian hipotesis kerja penelitian ini diterima. Artinya implementasi model terlangsung berpengaruh secara signifikan terhadap kecerdasan ekologis siswa pada siswa kelas kontrol.

\section{Uji Hipotesis Ketiga}

Sejalan dengan kenyataan bahwa model multiliterasi berbasis ecopedagogy approach maupun model terlangsung sama-sama mampu mengubah kecerdasan ekologis siswa siswa, perlu dilakukan perbandingkan kecerdasan ekologis siswa antara dua kelas. Guna meyakinkan bahwa kedua kelas yang dibandingkan memiliki kemampuan yang sama pada awal pembelajaran, sebelum melakukan pengujian perbedaan rerata postes perlu dilakukan pengujian rerata pretes antara kelas eksperimen dan kelas kontrol. Hasil pengujiannya adalah sebagai berikut.

Tabel 3 Hasil Uji Perbandingan Nilai Pretes Kecerdasan ekologis Siswa antara Kelas Eksperimen dan Kelas Kontrol

\begin{tabular}{|ll|r|l|}
\hline \multirow{2}{*}{} & & \multicolumn{2}{|c|}{ Pretes } \\
\cline { 3 - 4 } & & $\begin{array}{l}\text { Equal } \\
\text { variances } \\
\text { assumed }\end{array}$ & $\begin{array}{l}\text { Equal } \\
\text { variances } \\
\text { not } \\
\text { assumed }\end{array}$ \\
\hline $\begin{array}{l}\text { Levene's } \mathrm{F} \\
\text { Test for Sig. }\end{array}$ & .431 & \\
$\begin{array}{l}\text { Equality of } \\
\text { Variances }\end{array}$ & .512 & \\
\hline t-test for & $\mathrm{t}$ & 1.881 & 1.881 \\
Equality of & df & 258 & 257.207 \\
Means & Sig. (2-tailed) & .061 & .061 \\
& Mean Difference & 2.88462 & 2.88462 \\
& Std. Error Difference & 1.53345 & 1.53345 \\
& 95\% Confidence Lower & -.13505 & -.13510 \\
& Interval of the $\quad$ Upper & 5.90428 & 5.90433 \\
Difference & & \\
\hline
\end{tabular}

Berdasarkan tabel di atas dapat dikemukakan bahwa kedua data berdistribusi homogen dengan nilai $\mathrm{F}$ sebesar 0,43 dengan nilai signifikasi 0,51 yang lebih besar dari taraf nyata 0,05. Hasil perbandingan kemampuan pretes kecerdasan ekologis siswa antara kelas eksperimen dan kontol ditunjukkan dengan nilai $\mathrm{t}$ hitung sebesar 1,88 . Besaran nilai Sig. (2-tailed) adalah 0,061 . Ternyata nilai Sig. (2-tailed) lebih besar dibanding taraf signifikasi (alfa) 0,05. Hal ini berarti tidak terdapat perbedaan kecerdasan ekologis siswa pada saat pretes antara siswa di kelas eksperimen dan di kelas kontrol.

Sejalan dengan diketahuinya kesamaan kecerdasan ekologis siswa pada saat awal baik pada siswa kelas eksperimen maupun kelas kontrol, pengujian dilanjutkan dengan membandingkan perbedaan rerata kecerdasan ekologis siswa pada saat postes. Hasil pengujiannya adalah sebagai berikut. 
Tabel 4 Hasil Uji Perbandingan Nilai Postes Kecerdasan ekologis antara Kelas Eksperimen dan Kelas Kontrol.

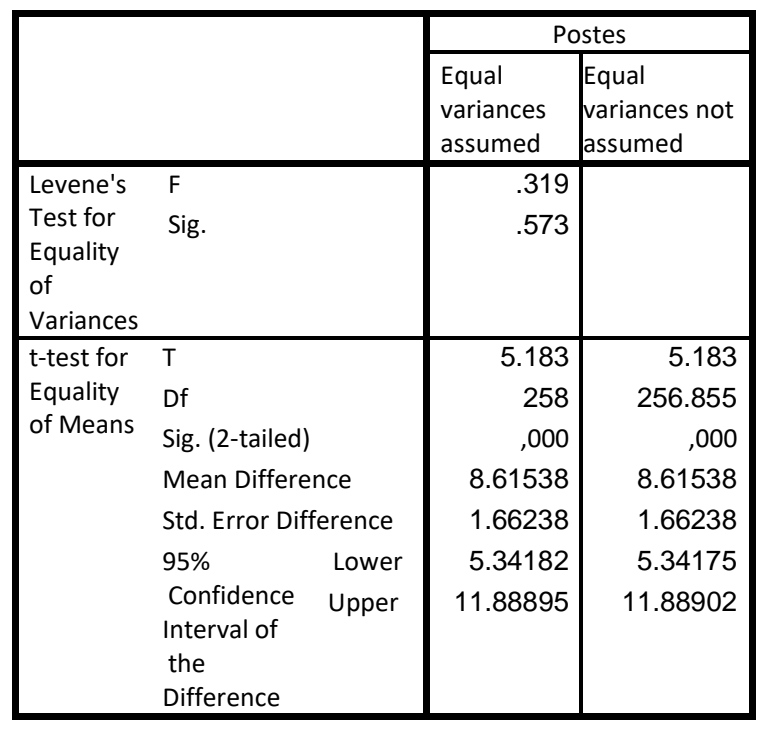

Berdasarkan tabel di atas dapat dikemukakan bahwa kedua data berdistribusi homogen dengan nilai $\mathrm{F}$ sebesar 0,319 dengan nilai signifikasi 0,573 yang lebih besar dari taraf nyata 0,05 . Hasil perbandingan kemampuan postes kecerdasan ekologis antara kelas eksperimen dan kontol ditunjukkan dengan nilai t hitung sebesar 5,18. Besaran nilai Sig. (2-tailed) adalah 0,00. Ternyata nilai Sig. (2-tailed) lebih kecil dibanding taraf signifikasi (alfa) 0,05. Hal ini berarti terdapat perbedaan kecerdasan ekologis pada saat postes antara siswa di kelas eksperimen dan di kelas kontrol. Hal ini berarti bahwa hipotesis kerja penelitian ini diterima artinya implementasi model multiliterasi berbasis ecopedagogy approach berpengaruh secara signifikan terhadap kecerdasan ekologis siswa sekolah dasar.

\section{Pembahasan}

Penelitian ini diawali dengan gagasan perlunya konsep pendidikan ekologis yang berorientasi pada upaya dalam membangun kesadaran dan kecerdasan ekologis pada peserta didik di jenjang sekolah dasar di Indonesia. Pendidikan ekologis bertujuan untuk mengasah sensibilitas ekologis serta menumbuhkan kesadaran akan keberadaan lingkungan hidup sebagai bagian dari ekosistem yang berpengaruh pada kehidupan manusia. Dalam dan melalui pendidikan ekologis, semua orang digiring kepada pembiasaan mentalitas hidup ekologis yang senantiasa sadar bahwa keberadaan dirinya hanya bisa berarti kalau ia ada bersama dengan ciptaan lain. Hal ini berimplikasi pada pemahaman tentang betapa bernilai dan berharganya alam bagi kehidupan manusia, sehingga betapa pentingnya untuk menjaga dan melestarikan kehidupan yang selaras dan seimbang.

Kesadaran ekologis harus menjadi bagian terpenting dari tujuan pendidikan. Pendidikan harus mampu membangun insan-insan pendidikan yang memiliki karakter dan kesadaran tentang alam/lingkungan dan bukan diorientasikan pada upaya untuk melahirkan insan-insan pendidikan yang berjiwa pragmatismaterialis, dan berdampak pada terbangunnya paradigma yang terjebak dalam rimba-raya pembangunan yang keliru (maldevelopment) yang hanya melihat alam sebagai obyek, mekanistis, terpecah-pecah, terpisah dari manusia sehingga mudah didominasi dan dieksploitasi.

Berkaitan dengan hal di atas, maka dapat dipahami, bahwa dalam kesadaran ekologis tidaklah dibangun melalui sebuah proses pendidikan yang hanya bersifat transfer of knowledge, melainkan sebuah proses pembelajaran yang menempatkan peserta didik sebagai subjek aktif dalam pembelajaran. Pendidikan yang membangun kesadaran dan kecerdasan ekologis dengan berorientasi pada transfer of knowledge hanya akan membuat peserta didik hanya sebatas memiliki pengetahuan tentang lingkungan, dan kurang memiliki kesadaran dan kepedulian terhadap lingkungan (Muhaimin, 2015). Hal inipun berdampak buruk pada karakter peserta didik yang pada umumnya belum bersikap 
dan berkelakuan ramah terhadap lingkungan.

Ekopedagogik dapat diartikan sebagai gerakan akademik untuk menyadarkan para peserta didik menjadi seorang individu yang memiliki pemahaman, kesadaran dan keterampilan hidup selaras dengan kepentingan pelestarian alam (Kahn, 2010). Dalam pengertian berbeda (Gadotti, 2010) berpendapat bahwa ekopedagogik merupakan sebuah pendekatan dalam pembelajaran yang menjadikan para peserta didik sebagai pembelajar yang mandiri, otonom, mampu mengembangkan potensi belajar berdasarkan pengalaman yang dibawa dari luar kelas serta menyadari bahwa setiap tindakannya berdampak pada diri dan lingkungannya. Sebagai sebuah pendekatan pembelajaran, ekopedagogik di dukung oleh teori kritis dan pedagogik kritis (Supriatna, 2016). Oleh sebab itu, pendidikan berbasis ekopedagogik dapat membangun kesadaran kritis dan mengembangkan karakter peserta didik untuk memahami hakikatnya sebagai manusia yang memiliki relasi dengan alam dan memanifestasikan kesadaran tersebut melalui perilaku bijak terhadap alam.

Berdasarkan hal tersebut, model multiliterasi berbasis pendekatan ekopedagogik menjadi salah satu konsep pembelajaran yang telah terbukti menjadi konsep pembelajaran yang dapat membangun kesadaran dan kecerdasan ekologis. Pada awalnya multiliterasi hanya dikenal dengan istilah literasi yakni alat yang dapat digunakan untuk beroleh dan mengomunikasikan informasi. Sejalan dengan perkembangan zaman, istilah ini terus berkembang menurut bidang ilmu tertentu dan dalam perkembangan terakhirnya bersinergi dengan kemajuan teknologi informasi dan komunikasi sehingga terbentuklah istilah multiliterasi. Cope dan Kalantzis (2005) sebagai penggagas awal istilah ini menyatakan bahwa penggunaan istilah multiliterasi didasarkan atas dua argumen yang erat hubungannya dengan budaya, institusi pendidikan, dan tuntutan global. Alasan pertama istilah digunakan adalah bahwa dalam mengomunikasikan informasi dapat digunakan beragam media dan alasan kedua adalah bahwa istilah ini memiliki arti yang sangat penting dalam meningkatkan arti penting bahasa dan budaya bagi perkembangan kapabilitas seseorang. Dengan demikian, pendidikan multiliterasi memiliki beragam fokus penggunaan bahasa yang akan sangat bergantung pada bidang ilmu yang dibahas, konteks budaya yang memengaruhinya, serta efek sosial yang dihasilkannya.

Berpijak pada hal di atas, penelitian ini telah membuktikan bahwa penerapan model multiliterasi berbasis ecopedagogy approach telah terbukti secara efektif membangun kesadaran dan kecerdasan ekologis. Hal ini didasarkan pada hasil perbandingan kemampuan postes kecerdasan ekologis antara kelas eksperimen dan kontol ditunjukkan dengan nilai t hitung sebesar 5,18. Besaran nilai Sig. (2-tailed) adalah 0,00. Ternyata nilai Sig. (2-tailed) lebih kecil dibanding taraf signifikasi (alfa) 0,05. Hal ini berarti terdapat perbedaan kecerdasan ekologis pada saat postes antara siswa di kelas eksperimen dan di kelas kontrol. Hal ini berarti bahwa hipotesis kerja penelitian ini diterima artinya implementasi model multiliterasi berbasis ecopedagogy approach berpengaruh secara signifikan terhadap kemampuan berpikir metakogisi siswa sekolah dasar.

Keberhasilan penelitian yang dilakukan ini sejalan dengan berbagai upaya mengimplementasikan konsep pembelajaran multiliterasi yang telah banyak dilakukan melalui beragam penelitian baik secara parsial maupun secara utuh mengkaji berbagai dimensi pembelajaran multiliterasi. Penelitian secara parsial berarti para peneliti hanya mengkaji salah satu dimensi pembelajaran multiliterasi baik dalam dimensi teori pedagogis, dimensi pembelajaran, dimensi 
bahan ajar, maupun dimensi evaluasi. Namun belum menyentuh pada tataran dimensi manusia yang salah satu diantaranya adalah dimensi eco-pedagogy sebagai bagian dari struktur fundamental pengembangan pembelajaran yang berorientasi pada upaya dalam membangun kesadaran dan kecerdasan ekologis pada siswa sekolah dasar.

Berdasarkan hasil penelitian yang telah dilakukan, keberhasilan penelitian ini sejalan dengan penelitian secara parsial terhadap konsep pembelajaran multiliterasi salah satunya dilakukan oleh Cope dan Kalantzis (2005) yang menghasilkan model multiliterasi yakni sebuah desain pedagogis yang terdiri atas 4 komponen penting mencakup situasi praktis, pembelajaran sistematis, bingkai kritis, dan transformasi praktis yang terbukti mampu meningkatkan kemampuan multiliterasi siswa.

Sejalan dengan kenyataan bahwa lingkup penelitian ini masih terbatas di sekolah penjajakan, perlu penelitian dengan subjek yang lebih luas. Oleh sebab itu, pada penelitian tahun berikutnya akan dilakukan penerapan model multiliterasi berbasis ecopedagogy approach dengan membangun sekolah percontohan dengan subjek penelitian yang lebih banyak. Melalui penerapan model multiliterasi ecopedagogy approach pada sekolah percobaan diharapkan variasi pola penerapan model multiliterasi berbasis ecopedagogy approach juga lebih bervariasi dan diperoleh gambaran hasil yang lebih komprehensif.

Berkaitan dengan hal di atas, upaya pengembangan penelitian selanjutnya akan dilakukan pada subjek lebih luas melalui pendekatan multibudaya pada objek wilayah yang memiliki karakteristik yang heterogen. Hal ini bertujuan untuk menggali unsur-unsur esensial pada setiap objek yang diharapkan mampu menjadi unsur/ nilai untuk membangun struktur fundamental pengembangan model multiliterasi berbasis ecopedagogy approach.

\section{KESIMPULAN}

Berdasarkan hasil penelitian dan analisis data hasil penelitian, penelitian ini menyimpulkan beberapa simpulan tentang beberapa hal esensial meliputi pola-pola implementasi Model multiliterasi berbasis Ecopedagogy Approach meliputi: Transformasi nilai kesadaran, penghayatan kesadaran lingkungan dan manifestasi kesadaran lingkungan. Selain itu, implementasi Model multiliterasi berbasis Ecopedagogy Approach telah terbukti berpengaruh secara signifikan terhadap kecerdasan ekologis pada siswa kelas eksperimen. Hal ini menandakan bahwa Model multiliterasi berbasis Ecopedagogy Approach mampu meningkatkan kecerdasan ekologis dan karakter siswa pada jenjang sekolah dasar secara efektif pada berbagai bidang kajian yang diajarkan.

Implementasi Model multiliterasi berbasis Ecopedagogy Approach terlangsung berpengaruh secara signifikan terhadap kecerdasan ekologis dan karakter pada siswa kelas kontrol. Hal ini menandakan bahwa model terlangsung juga sebenarnya telah mampu meningkatkan kecerdasan ekologis siswa pada jenjang sekolah dasar secara efektif pada berbagai bidang kajian yang diajarkan. Implementasi Model multiliterasi berbasis Ecopedagogy Approach telah terbukti lebih baik dalam meningkatkan kecerdasan ekologis dan karakter siswa jika dibandingkan dengan model terlangsung yang biasanya digunakan di sekolah. Hal ini menandakan bahwa model multiliterasi berbasis Ecopedagogy Approach lebih mampu meningkatkan kecerdasan ekologis dan karakter siswa pada jenjang sekolah dasar secara efektif pada berbagai bidang kajian yang diajarkan dibandingkan dengan model terlangsung yang biasanya digunakan di sekolah dasar.

Berdasarkan simpulan di atas, adapun penelitian ini mengajukan beberapa saran bahwa Model multiliterasi berbasis Ecopedagogy Approach lebih 
efektif dalam meningkatkan kecerdasan ekologis dan karakter siswa sekolah dasar dibandingkan dengan model terlangsung, sekolah disarankan mengimplementasikan model multiliterasi berbasis Ecopedagogy Approach dalam praksis kegiatan pembelajaran. Penerapan Model multiliterasi berbasis Ecopedagogy Approach harus didukung oleh kerja sama antar elemen, baik antara guru, dan pihak manajemen sekolah. Hal ini perlu dilakukan agar terwujudnya efektivitas pembelajaran yang bermutu, sehingga memberi implikasi pada berkembangnya potensi dan berkembangnya kesadaran ekologis siswa siswa. Selain itu, erlu penelitian lanjutan dengan subjek penelitian lebih banyak dan pembentukan sekolah percontohan serta penambahan bidang ilmu yang diintegrasikan sehingga keberhasilan implementasi Model multiliterasi berbasis Ecopedagogy Approach menjadi lebih komprehensif dan menyeluruh pada seluruh bidang ilmu yang diajarkan di sekolah dasar.

\section{DAFTAR PUSTAKA}

Concannon-Gibney, T. dan McCarthy, M.J. (2012) "The Explicit Teaching of Reading Comprehension in Science Class: a Pilot Professional Development Program". Improving Schools. 15 (1). 73-88.

Cope, B. dan Kalantzis, M. (2005). Multiliteracies: Literacy Learning and the Design of Social Futures. New York: Routledge.

Cresswell, J.W.(2007). Mixed Method. London: Sage Publicational.

Freire, P. (2010). Pedagogy of the oppressed. New York: The Continuum International Publishing Group Inc.

Gadotti, M (2010). Reorienting Education Practices towards Sustainability. Journal of Education for Sustainable Development, 2 (4), 203-211

Herlambang, Y T, (2018). Pedagogik: Telaah Kritis Ilmu Pendidikan
Dalam Multiperspektif. Jakarta: Bumi Aksara.

Ivanic, R. (2009). “Bringing Literacy Studies into Research and Prospects" dalam The Future of Literacy Studies. New York: Palgrave MacMillan.

Iyer, R. \& Luke, C. (2010). Multimodal, Multiliteracies: Texts and Literacies for the 21 st Century. dalam Pullen \& Cole (Eds.). Multiliteracies and Technology Enhanced Education: Social Practice and the Global Classroom. New York: Information Science Reference (an imprint of IGI Global).

Kahn, R. 2010. Critical pedagogy, ecoliteracy \& planetary crisis. The ecopedagogy movement. NY: Peter Lang.

Machan, T, R. (1989). Liberty and Culture: Essay on the Idea of a Free Society. New York: Prometheus Books.

Misiaszek, G. W. (2012). Transformative environmental education within social justice models: Lessons from comparing adult ecopedagogy within North and South America. In D. N. Aspin, J. Chapman, K. Evans \& R. Bagnall (Ed.).Second international handbook of lifelong learning (Vol. 26, pp. 423-440). London: Springer.

Muhaimin, (2015). Implementasi Model Pembelajaran Berbasis Masalah Lokal dalam mengembangkan kompetensi ekologis pada Pembelajaran IPS. Sosio didaktika. Social science educational journal. 1(2).

Soemarwoto (2001). Atur Diri Sendiri: Paradgima Baru Pengelolaan Lingkungan Hidup. Yogyakarta: Gajah Mada University Press.

Supriatna, N. (2016). Ecopedagogy. Bandung: Rosdakarya.

Supriatna. N. (2002). Kecerdasan Ekologis. Bandung: Alfabeta.

Yunansah, H, \& Herlambang, Y T. (2017). Pendidikan Berbasis Ekopedagogik 
Dalam Menumbuhkan Kesadaran

Ekologis Dan Mengembangkan

Karakter Siswa Sekolah Dasar:

Sebuah Telaah Kritis Dalam

Perspektif Pedagogik Kritis.

Eduhumaniora: Jurnal Pendidikan

Dasar. 9 (1), 27-38. 